\title{
Cell density-dependent swimming patterns of Alexandrium fundyense early stationary phase cells
}

\author{
Agneta Persson ${ }^{1,3}$, Barry C. Smith ${ }^{2, *}$ \\ ${ }^{1}$ Department of Biological and Environmental Sciences, Göteborg University, Box 461, 40530 Göteborg, Sweden \\ ${ }^{2}$ National Oceanic and Atmospheric Administration, National Marine Fisheries Service, Northeast Fisheries Science Center, \\ Milford Laboratory, Milford, Connecticut 06460, USA \\ ${ }^{3}$ Present address: Smedjebacksvägen 13, 77190 Ludvika, Sweden
}

\begin{abstract}
Different life-history stages of Alexandrium fundyense have different swimming behaviors and show different responses to water movement. Early stationary phase cells assemble in bioconvection patterns along the water surface and as stripes in the water, while cells in exponential growth do not. We studied the swimming behavior of early stationary phase A. fundyense cells, both on the individual level and on the population level. Cells assembled in spots in shallow Petri dishes, and were studied using an inverted microscope. We analyzed 53 videos of cells at different distances from the center of accumulated spots of cells with the program CellTrak for swimming behavior of individual cells. The closer the cells were to the center of spots, the faster they swam ( $>600 \mu \mathrm{m} \mathrm{s}^{-1}$ in the center of spots compared to ca. $300 \mu \mathrm{m} \mathrm{s}^{-1}$ outside) and the more often they changed direction ( $>1400$ degrees $\mathrm{s}^{-1}$ in the center compared to $<400$ degrees $\mathrm{s}^{-1}$ outside). On a population level, the behavior of spots of assembled cells was studied using time-lapse photography. The spots entrained more and more cells as they grew and fused with each other; the closer the spots came to each other, the faster they moved until they fused. We suggest that chemical attraction between gametes causes the observed behavior.
\end{abstract}

KEY WORDS: Alexandrium fundyense $\cdot$ Swimming pattern $\cdot$ Stationary phase $\cdot$ Gamete $\cdot$ Cell density

Resale or republication not permitted without written consent of the publisher

\section{INTRODUCTION}

Early stationary phase cultures of dinoflagellates often show patterns of accumulating cells, whereas during exponential growth they are well dispersed. Cells in early stationary phase accumulate in lines along and perpendicular to the wall and water meniscus in flasks. In shallow containers, such as Petri dishes, cells form spots instead (e.g. Uchida 2001). When in salinity-stratified containers, cells in this state (early stationary, nitrogen starved, or in encystment medium) accumulate in the pycnocline layer (Tyler et al. 1982, Rasmussen \& Richardson 1989, Doblin et al. 2006, Persson et al. 2008).
The phenomenon of pattern formation by motile microorganisms in aqueous media is well known and termed 'bioconvection' (e.g. Pedley \& Kessler 1992, Hill \& Pedley 2005). The first quantitative study of the phenomenon was published by Wager (1911). The basic mechanism explaining this phenomenon is similar to thermal or Rayleigh-Bénard convection, but the overturning instability is not caused by temperature differences, rather it is the result of the collective behavior of many microorganisms. These cells are slightly denser than the medium and aggregate due to tactic behavior. The situation that has most often been studied is when photo- and gravitactic microorganisms, denser than water, swim upward and accumulate in such large 
amounts that they cause an unstable density stratification that triggers instability in the form of descending plumes of cells (Kessler 1985, 1986, Pedley \& Kessler 1992, Bees \& Hill 1997, Hopkins \& Fauci 2002, Nguyen-Quang et al. 2009). In such a plume, the fluid velocity is higher than the swimming velocity of individual cells - the collective behavior of cells has changed the density distribution in such a way that patterns are formed at a scale greater than individual cells. The underlying cause of the assemblage of cells is a tactic behavior of individual cells, being attracted to light, nutrients, oxygen, etc., or swimming upwards to avoid sinking (gravitaxis). When geometry of cells, density distribution within cells, placement of flagella, etc. affects the swimming direction, the term used is gyrotaxis. Gyrotaxis is directional swimming due to a combination of upward swimming and rotational drag due to shear (e.g. Kessler 1985, Durham et al. 2009). Bioconvection patterns concentrate microorganisms into dense regions separated by regions with few organisms, which can facilitate mating (Wager 1911, Kessler 1986, Pedley \& Kessler 1992).

In many dinoflagellate species, including all that produce resting cysts, gametes are formed at the end of the growth season. Attraction between gametes is necessary, otherwise sexual fusion and production of resting cysts for survival during the winter would be impossible. The 'season cue' for gamete formation may be composed of many different kinds of information, among which a low-nitrogen signal apparently is important (Persson et al. 2008 and references therein). In cultures, gametes are formed in encystment medium (often low-nitrogen medium, e.g. Persson et al. 2008), and also in growth medium when nutrients become depleted at the beginning of stationary phase.

We studied the assembly of early stationary-phase cells in dense spots and the swimming patterns of cells inside and outside spots; the behavior and movement of the assembled spots was also studied. Alexandrium fundyense is a heterothallic species that requires the presence of a sexually compatible clone for successful mating and zygote and resting cyst production. In other experiments (Persson et al. 2013) we have shown that formation of gametes occurs in encystment medium irrespective of the presence of a compatible strain, resulting in a prolonged swarming time in the absence of compatible gametes. Zygotes do form within one single strain, but seldom successfully continue to form resting cysts, but a single strain can still be used to study gamete behavior.

\section{MATERIALS AND METHODS}

The experiment was performed from 22 to 30 April 2009 on cultures of Alexandrium fundyense (strain 38-3 from the Woods Hole Oceanographic Institution) that had been inoculated on 1 April; they were in early stationary phase, with cultures displaying accumulation patterns. Several batch cultures had been inoculated on different dates to enable the choice of cultures in the desirable, pattern-forming state at the time of the experiment. Video 1 (see the supplement at www.int-res.com/ articles/suppl/a068p251_supp/) illustrates the difference between pattern-forming and non-patternforming cultures. Both have the same cell density, but the culture not forming patterns contains logphase, vegetative cells concentrated to the same cell density for comparison.

Cultures (125 ml) were grown in $500 \mathrm{ml}$ Erlenmeyer flasks in a bioincubator with light at $300 \mu \mathrm{E}$ $\mathrm{m}^{-2} \mathrm{~s}^{-1}, 14 \mathrm{~h}$ light:10 $\mathrm{h}$ dark and $20^{\circ} \mathrm{C}$. The experiments were performed in polystyrene Petri dishes (35 $\mathrm{mm}$ diameter) in a culture room with $24 \mathrm{~h}$ light at $100 \mu \mathrm{E} \mathrm{m} \mathrm{m}^{-2} \mathrm{~s}^{-1}$ and $20^{\circ} \mathrm{C}$ using $3 \mathrm{ml}$ aliquots of the cultures without change of medium (cell density 24200 cells $\times \mathrm{ml}^{-1}, 4 \mathrm{~mm}$ depth of liquid $\approx 110$ cell diameters).

\section{Movement of individual cells}

Digital video files were captured in the same culture room with an inverted Olympus microscope and a ProScope HR digital video camera (www.bodelin. com/proscopehr/). Recording was done using the $4 \times$ objective of the microscope and a $10 \times$ magnifying attachment tube for the camera. Video acquisition was for continuous, $20 \mathrm{~s}$ time periods, with the resolution set at $320 \times 240$ pixels and the frame rate at 30 frames $\mathrm{s}^{-1}$. The area of the frame at this resolution was $1 \mathrm{~mm}^{2}$. Fifty-three video files were captured at different distances from the center, and in the center of circular spots that had been formed in the Petri dishes by accumulating cells.

Motion analysis was performed with the software CellTrak 1.5 (Motion Analysis Corporation), and software-measured, motion parameters analyzed were: speed, net to gross displacement ratio (NGR) and rate of change of direction (RCD). Explanations for these variables follow.

For a given point in a path, the net displacement is the distance along a straight line from the first point in the path to the given point. In contrast, the gross 
displacement is the distance along the actual path from the first point in the path to the given point. The ratio between these 2 quantities is called the NGR. The NGR is a dimensionless number between 1 and $0 ;$ it is an index of path irregularity or contortion. Simple, linear (straight line) movement results in a NGR of 1 ; repeated circular motion results in a declining NGR which approaches 0 with time (Snyder et al. 2003). The RCD, or angular velocity, is the turning frequency of the cell in units of degrees per second (Lopez-de-Victoria et al. 1995). It is calculated for each frame as the unsigned difference in angle of travelling direction from the previous frame, multiplied by the frame rate (CellTrak Algorithms, Motion Analysis Corporation).

Data describing the tracks were exported to Excel, and average speed, NGD and the RCD for each file were compared for different cell densities. The number of cells in each video was counted as the average counts of cells in the first and last frame.

\section{Movement of spots}

Time-lapse videos were made of spots in Petri dishes (35 mm diameter) in the following way: 6 Petri dishes containing $5 \mathrm{ml}$ culture (5 with 24200 cells $\times$ $\mathrm{ml}^{-1}$, and the sixth with an unknown but higher cell density taken with a Pasteur pipette from dense accumulations of swarming cells in a flask) were mixed gently by hand to distribute cells evenly. The dishes were recorded using time-lapse video (1 frame $\mathrm{s}^{-1}$ for $25 \mathrm{~min}=300$ frames), without magnification, at a resolution of $640 \times 480$ pixels, until spots were united. This was repeated 3 times.

Analysis of spot movement was made by saving every tenth frame from 1 video file with the software VirtualDub (www.virtualdub.org). The frames were analyzed using the software ImageJ (http:// rsbweb.nih.gov/ij/); the center of each spot was given a number and position ( $x$ and $y$ coordinates), and these coordinates were exported to Excel. By following the movement of the center of each spot, the speed could be calculated.

Samples were taken for cell counts after video recording. Culture samples were taken from accumulations of cells and outside accumulations with a syringe and counted with a flow cytometer (FACScan, BD BioSciences) and in a microscope with cells preserved with iodine using a Sedgwick-Rafter counting chamber. Cell numbers in spots were also estimated from video files.

\section{Mating and resting cyst formation}

Mating experiments were performed with the swarming cells in a separate experiment, combining them with the Clone BF-2 (from the Milford Laboratory culture collection) and the Strain GTM-253-17 (from the Woods Hole Oceanographic Institution) in equal numbers in multi-well dishes. Methods for cyst production are described in Smith \& Persson (2004). The dishes were observed for mating behavior and resting-cyst formation for $2 \mathrm{mo}$.

Polynomial regression analysis was done using the software StatGraphics Plus 5.1. (Statpoint Technologies).

\section{RESULTS}

\section{Movement of individual cells}

The higher the cell number, the faster individual cells swam. The cell speed was highest in the center of the spots and lower outside (Fig. 1). A quartic polynomial regression model gave the best fit to the data $\left(\mathrm{R}^{2}=0.95\right):$ speed $=338-1.53 \times N+2.69 \times 10^{-2} \times N^{2}$ $-8.70 \times 10^{-5} \times N^{3}+8.38 \times 10^{-8} \times N^{4}$, where $\mathrm{N}$ is the number of cells per square millimeter.

As can be seen in Fig. 2, cells that were distant from each other swam straight (the NGD was high),

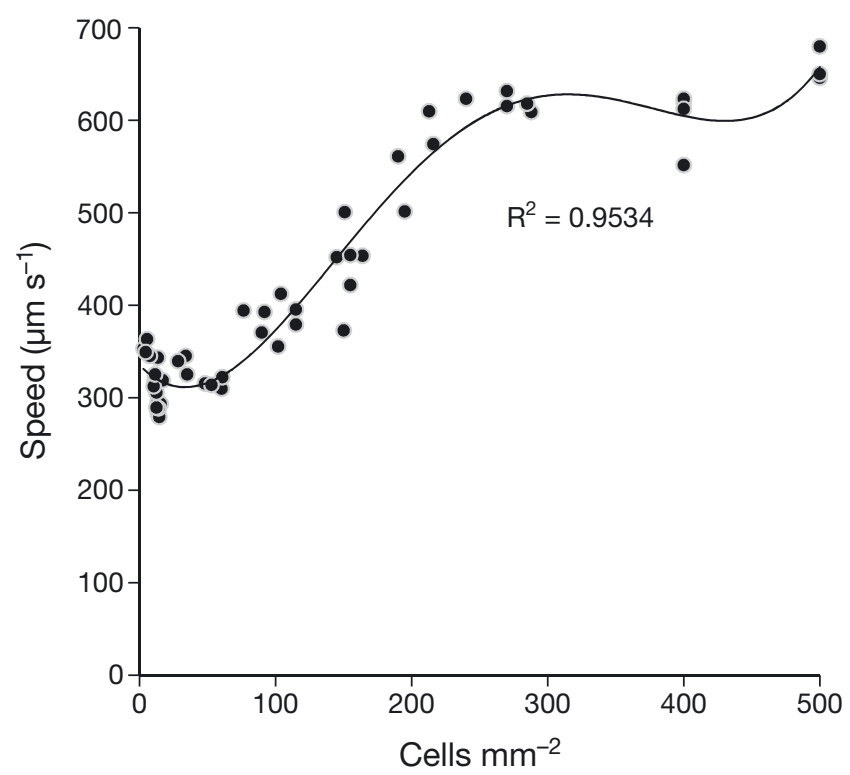

Fig. 1. Alexandrium fundyense. The speed of individual cells at different distances from the center of accumulated spots of cells is described by the quartic polynomial regression; see

'Results; Movement of individual cells' for more detail 
whereas cells in close proximity to each other did not. The function NGD $=0.772-2.17 \times 10^{-3} \times N+1.21 \times$ $10^{-5} \times N^{2}-2.88 \times 10^{-8} \times N^{3}+2.35 \times 10^{-11} \times N^{4}$, describes the relationship $\left(R^{2}=0.86\right)$.

The rate at which cells changed direction (RCD) is presented in Fig. 3, and is related to cell density by the equation of the fitted model: $\mathrm{RCD}=350+5.87 \times$ $N-1.31 \times 10^{-2} \times N^{2}+1.10 \times 10^{-5} \times N^{3}\left(\mathrm{R}^{2}=0.97\right)$. The swimming direction of the cells was changed often in the center of spots, where many cells were present, while there were few direction changes outside spots. Cells moved constantly towards the center of spots, there they descended and then scattered radially (as seen from below with the inverted microscope).

\section{Movement of spots}

The movements of 'spots' of accumulated cells were observed to occur in the same way in each dish and in each repeated trial. Spots were formed within minutes after shaking the dishes (often in $<1 \mathrm{~min}$ ), and these immediately started moving toward each other until they united. The average speed of the spots was $17.8 \pm 7.8 \mu \mathrm{m} \mathrm{s}^{-1}$ when moving toward each other. Upon uniting, the speed increased to an average of $49.5 \pm 12.3 \mu \mathrm{m} \mathrm{s}^{-1}$. The movements are described in Fig. 4 for 1 Petri dish, and in time-lapse

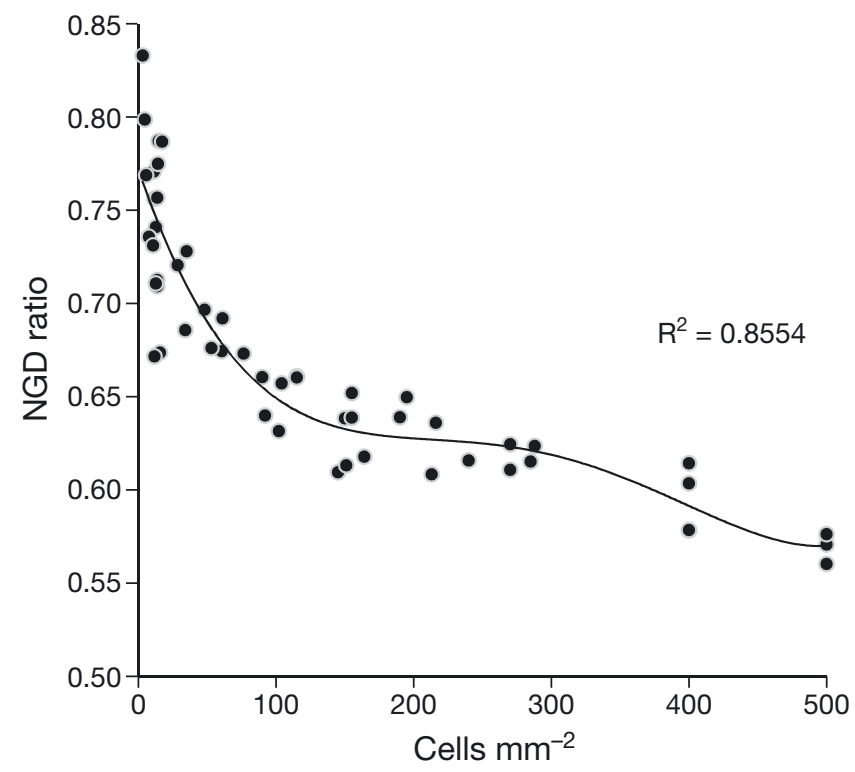

Fig. 2. Alexandrium fundyense. The net-to-gross-displacement (NGD) ratio of cells describes how straight their movement is. Zero describes circular movement, and 1, a straight line. A polynomial regression of the fourth order (quartic) fits the data; see 'Results; Movement of individual cells' for more detail videos (in the supplement at www.int-res.com/ articles/suppl/a068p251_supp/). Video 2 describes pattern formation in dishes, Video 3 shows dishes with vegetative cells at the same cell density as in Video 2, and Video 4 shows a flask with accumulation patterns.

Cell numbers in the spots were $84.8 \pm 12.0$ cells $\mathrm{l}^{-1}$ when sampled with a syringe and preserved for microscope counting and $170 \pm 28.8$ cells $_{\mu l}^{-1}$ when counted live with the flow cytometer. In contrast, cell numbers in empty spaces on the same dish were as low as $0.1 \pm 0.4$ cells $_{\mu l^{-1}}$ (microscope) or $1.8 \pm 0.09$ cells $\mathrm{\mu l}^{-1}$ (flow cytometer). Sampling densely accumulated cells with a syringe probably did not yield accurate numbers because of practical difficulties in sampling the small volume of the spot only, and not the water surrounding it. When cell numbers were counted in video frames, the area observed was $1 \mathrm{~mm}^{2}$. The visual depth was approximately 4 or 5 cell diameters. As $>500$ cells could be observed within 1 frame in the center of dense spots (Figs. 1 to 3), the cell density in the observed volume at the very center of spots was estimated at approximately 3000 cells $\mu \mathrm{l}^{-1}$.

\section{Mating and resting cyst formation}

Mating and resting cyst formation were observed for both combinations of strains (38-3 + BF-2 and 38-

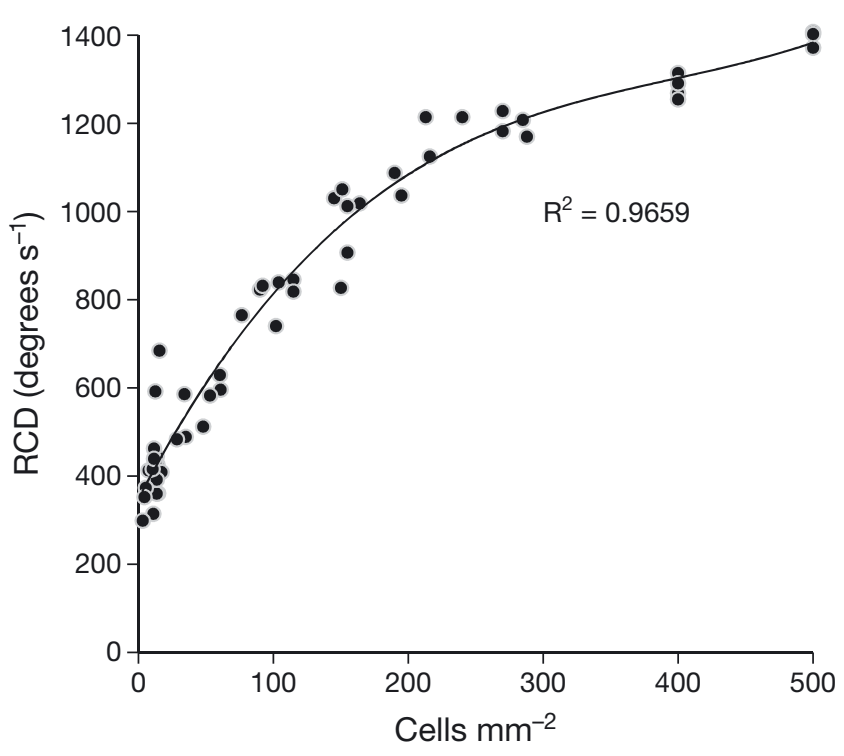

Fig. 3. Alexandrium fundyense. Rate of change of direction (RCD) of cells: a polynomial regression of the third order (cubic) describes the data; see 'Results; Movement of individual cells' for more detail 


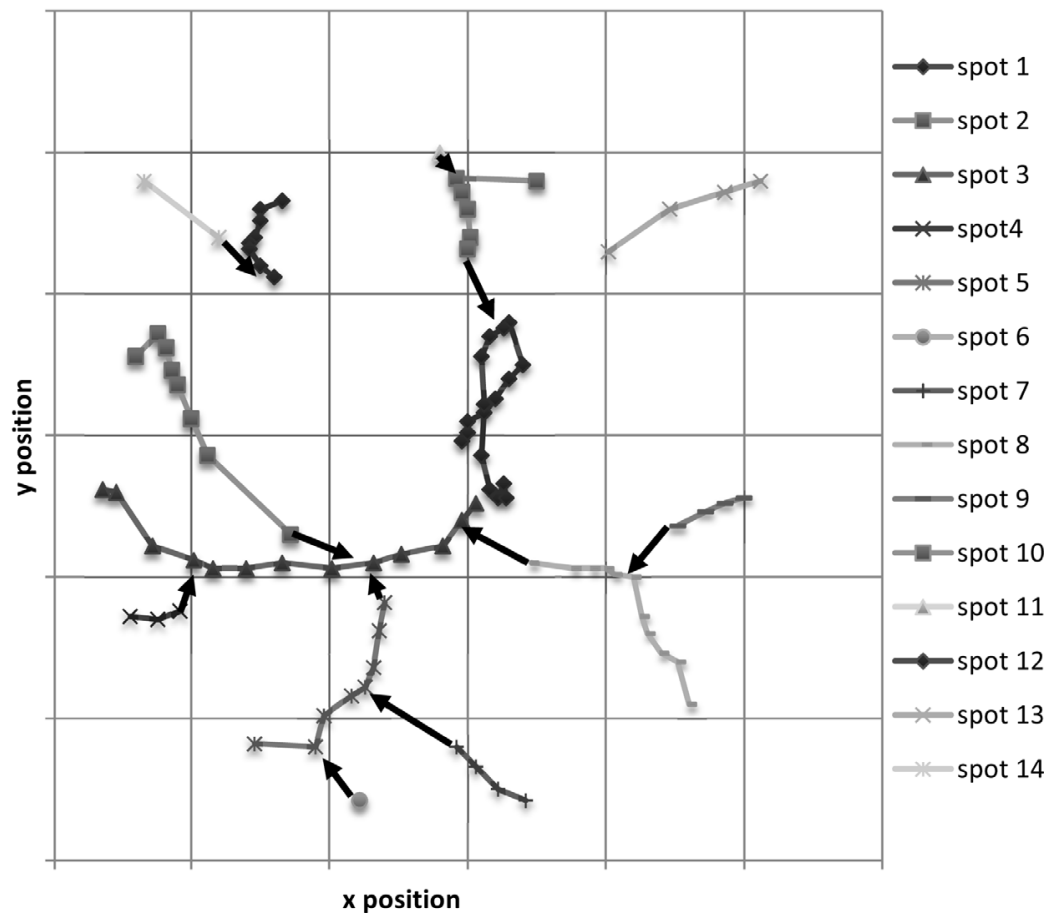

Fig. 4. Alexandrium fundyense. Movement of spots within a Petri dish with early stationary phase cells, as viewed from above. Each mark corresponds to the position of each spot every $10 \mathrm{~s}$. Black arrows indicate the last movement before uniting (direction indicated by arrows); in the next frame, spots were united. Small spots were first seen around the periphery of the dish; these then moved toward each other and united. Spots moved to the center and united with the increasingly larger spot in the middle of the dish

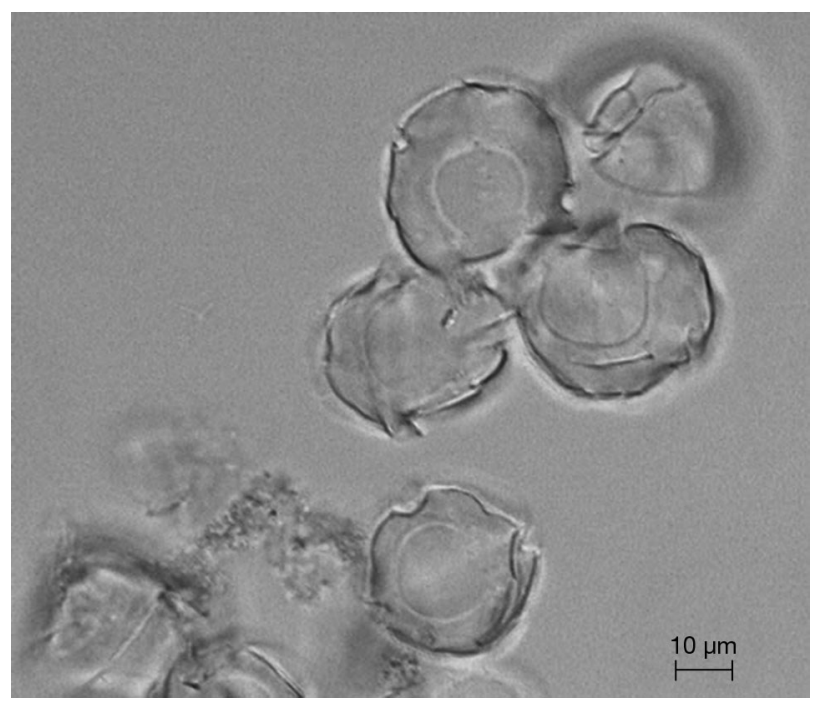

Fig. 5. Alexandrium fundyense. Empty thecae with circular membranes left inside. Picture from culture in encystment medium ( $f / 2$ without $N)$

3 + GTM-253-17). Commingling cells from swarms in cultures resulted in more successful mating than using samples from flasks that were swirled gently first to mix all life stages evenly. Empty thecae with a circular membrane inside (Fig. 5) of both gamete/ vegetative cell size and the larger zygote cell size were observed.

\section{DISCUSSION}

Alexandrium fundyense growing exponentially do not form patterns in the same way as they do in early stationary phase or in encystment medium. When in early stationary phase, they create patterns in the water that persist during the day and that quickly re-form after shaking (within a minute), while shaking cultures in exponential growth does not result in rapid re-formation of patterns. The life-history stage affects swimming patterns and responses to water movement in Alexandrium fundyense, and we suggest that this is due to differences in tactic behavior.

We demonstrate here, using standard optical instruments combined with video-analysis tools, that swimming patterns in early stationaryphase cultures of Alexandrium fundyense are coordinated precisely and are dependent upon cell proximity. Cells swam faster and made more cell contacts per cell and time unit the greater the density of cells. A plausible explanation for this would be that it was a chemosensory phenomenon; a substance (possible pheromone) was released continuously by gametes, or upon cell contact, and created a concentration gradient surrounding the colliding cells. A gradient detected by other cells could define a certain direction, attracting other cells to places with many cells. The molecular diffusion in seawater is known to be approximately $1 \times 10^{-5} \mathrm{~cm}^{2} \mathrm{~s}^{-1}$, but differs between substances (Hayduk \& Laudie 1974), and chemical signaling is well known among other organisms in the sea (Hay 2009). We have observed repeatedly that gametes, in contrast to vegetative cells, are attracted to and move faster near container walls (Smith \& Persson 2004, 2005, Persson et al. 2008) and objects such as inserted materials or debris (A. Persson \& B. C. Smith unpubl. obs.). Swimming organisms at low Reynolds numbers are coupled to each other and to nearby surfaces by the flows associated with their locomotion (Cisneros et al. 2007). 
The wall effect allows cells to move faster when the reverse motion of the fluid is impeded by the adjacent wall, but the wall effect alone cannot explain differences in swimming behavior between life-cycle stages. The surroundings, thus, influence the behavior of individual cells of varying life-history stages differently. It can be argued that being in a crowd automatically leads to the necessity of direction change and cell contacts, but it should not lead to a higher speed, as change of direction leads to stops with a need for acceleration to resume fast movement. Random movements cause dispersal, not accumulation. Resting cyst formation was more successful using swarming cells than mixed cultures, confirming that pattern-forming cells were gametes or about to soon become gametes.

The cells assembled in patterns of lines and stripes along the surface near the wall. Pattern formation is well known among motile microorganisms that display tactic behavior (e.g. photo-, gravi-, gyro-, or chemotaxis; reviewed in Pedley \& Kessler 1992 and Hill \& Pedley 2005) and lead to regions where cells are densely accumulated, thereby facilitating mating (Wager 1911, Kessler 1986, Pedley \& Kessler 1992). A thorough description of swimming behavior of individual cells of different life stages of Alexandrium fundyense is provided in Persson et al. (2013). We have observed repeatedly (A. Persson \& B. C. Smith unpubl. obs.) that, when dinoflagellate cells are in early stationary phase, they create patterns in the water that persist during the day and that quickly reform after shaking (within a minute), while shaking cultures in exponential growth does not result in reformation of patterns. Walking with cells in this state in a Petri dish causes the cells to assemble in a spot in the middle of the dish, while walking with a dish with cells that are not in a pattern-forming mode does not create a spot. Thus, different life-history stages show different swimming patterns and different responses to water movement.

Dinoflagellates move in a 3-dimensional environment, and details of the motions of vegetative cells have been studied often, in both 2-dimensional (e.g. Kamykowski et al. 1988, Kamykowski 1995, McKay et al. 2006) and 3-dimensional domains (e.g. Fenchel 2001, Lewis et al. 2006, Sohn et al. 2011). The flagellar apparatus has been studied in detail (e.g. Miyasaka et al. 1998), and dinoflagellates are known to exert fine control over their movements (e.g. Levandowsky \& Kaneta 1987). The present study points to the need for similar research on gametes.

Upon recognition of a mating-season signal, it takes at least $2 \mathrm{~d}$ before gametes are formed/display their typical contact-seeking behavior and start mating (2 to $3 \mathrm{~d}$ in our experiments with Alexandrium fundyense and Scrippsiella lachrymosa, 2 to $4 \mathrm{~d}$ for Lingulodinium polyedrum [Figueroa \& Bravo 2005] and also for Alexandrium tamutum and A. minutum [Figueroa et al. 2007]). Some kind of physical and/or metabolic change thus seems to be necessary for the transformation from vegetative cell to gamete, although both are haploid. Only gametes and not vegetative cells can fuse. Cells might have to make one more division to become gametes, and/or change the theca by shedding. We have repeatedly observed shedding of the theca, but this action is not fully understood. A new surface membrane might be necessary to allow fusion; fusion of cells in organisms where this has been studied in detail (plants, animals, other protists) is highly regulated and not a process possible for vegetative or somatic cells (Epand 2000). When dinoflagellate gametes fuse, the fusion has been observed to be total, including the entire cell surface (e.g. Chesnick \& Cox 1989). The presence of specialized processes for recognition, attachment and fusion is likely, but so far unstudied. In A. fundyense and many other thecate dinoflagellates, the theca divides diagonally during cell division, and each new cell forms a new half theca (Steidinger \& Tangen 1997, Probert et al. 2002); an intact theca is not shed during this division. When placed in encystment medium, from Day 2 many empty thecae appear at the bottom of the culture vessel (that can also be seen in old cultures); these are intact cell walls that have a circular membrane remaining inside (Fig. 5). We have noted the shedding of thecae both by gamete formation and by newly formed zygotes.

Since undisturbed blooms of Alexandrium fundyense are known to end with cyst formation (e.g. Anderson et al. 2012), and cyst formation by necessity has to be preceded by gamete formation, a large proportion of the cells in a bloom are likely to be gametes. The microscopic movements of individual cells in the field during a dinoflagellate bloom are unknown, but when cells are in salinity-stratified conditions similar to those that occur during a bloom, they are known to accumulate in the halocline (e.g. Wyatt \& Jenkinson 1997, Smayda 2002). Durham et al. (2009) describe a model for hydrodynamic trapping of motile microorganisms in layers. It is well known that upwelling, currents and fronts are important for dinoflagellate bloom formation and transport (Tyler et al. 1982, Anderson 1998, Anderson et al. 1998). The interaction between life-stage-dependent swimming behavior, water movements and stratification is probably of great importance to understand 
the formation and development of dinoflagellate blooms. The present study suggests that gamete assembly on a micro-scale can be the underlying cause for large-scale phenomena seen as patchy discolorations of water and dense accumulations of dinoflagellates in thin layers.

\section{CONCLUSIONS}

Early stationary phase cells of Alexandrium fundyense accumulated and formed patterns in the water, in which cells swam faster the more of them there were in the same place. The cells achieved cell contact increasingly and changed direction frequently. Spots of assembled cells were attracted to other spots and fused to form larger assemblages. Large spots attracted smaller spots that moved toward them and united. Addition of swarming cells to a sexually compatible strain quickly resulted in mating and zygote formation, followed by resting cyst formation. We suggest chemical attraction by a substance excreted by gametes (either continuously or upon cell contact) as a means for forming a gradient that is direction-giving for gametes and groups of gametes.

Acknowledgements. The Magnus Bergvall's Foundation and Oscar and Lili Lamm's Foundation provided financial support. We are grateful to Jennifer Alix for assistance with culturing, Dr. Gary H. Wikfors for manuscript advice, anonymous reviewers for valuable comments on an earlier version of the manuscript and Dr. John O. Kessler for valuable information on bioconvection.

\section{LITERATURE CITED}

Anderson DM (1998) Physiology and bloom dynamics of toxic Alexandrium species, with emphasis on life cycle transitions. In: Anderson DM, Cembella AD, Hallegraeff GM (eds) The physiological ecology of harmful algal blooms. Springer, Berlin, p 29-48

Anderson DM, Geyer WR, Butman B, Signell RP, Franks PJS, Loder TC III (1998) Source population dynamics of 'red tide' dinoflagellates in the southwestern Gulf of Maine coastal current. RMRP Final Technical Report, Project GMR-20, available at http://woodshole.er.usgs. gov/operations/modeling/wgulf/final_report/rmrp_final. htm

Anderson DM, Cembella AD, Hallegraeff GM (2012) Progress in understanding harmful algal blooms: paradigm shifts and new technologies for research, monitoring, and management. Ann Rev Mar Sci 4:143-176

Bees M, Hill NA (1997) Wavelengths of bioconvection patterns. J Exp Biol 200:1515-1526

> Chesnick JM, Cox ER (1989) Fertilization and zygote development in the binucleate dinoflagellate Peridinium balticum (Pyrrhophyta). Am J Bot 76:1060-1072

Cisneros LH, Cortez R, Dombrowski C, Goldstein RE, Kessler JO (2007) Fluid dynamics of self-propelled microorganisms, from individuals to concentrated populations. Exp Fluids 43:737-753

Doblin MA, Thompson PA, Revill AT, Butler ECV, Blackburn SI, Hallegraeff GM (2006) Vertical migration of the toxic dinoflagellate Gymnodinium catenatum under different concentrations of nutrients and humic substances in culture. Harmful Algae 5:665-677

Durham WM, Kessler JO, Stocker R (2009) Disruption of vertical motility by shear triggers formation of thin phytoplankton layers. Science 323:1067-1070

Epand RM (2000) Membrane fusion. Biosci Rep 20:435-441

Fenchel T (2001) How dinoflagellates swim. Protist 152: 329-338

Figueroa RI, Bravo I (2005) Sexual reproduction and two different encystment strategies of Lingulodinium polyedrum (Dinophyceae) in culture. J Phycol 41:370-379

Figueroa RI, Garcés E, Bravo I (2007) Comparative study of the life cycles of Alexandrium tamutum and Alexandrium minutum (Gonyaulacales, Dinophyceae) in culture. J Phycol 43:1039-1053

Hay ME (2009) Marine chemical ecology: chemical signals and cues structure marine populations, communities, and ecosystems. Ann Rev Mar Sci 1:193-212

> Hayduk W, Laudie H (1974) Prediction of diffusion coefficients for nonelectrolytes in dilute aqueous solutions. AlChE J 20:611-615

> Hill NA, Pedley TJ (2005) Bioconvection. Fluid Dyn Res 37: $1-27$

> Hopkins MM, Fauci LJ (2002) A computational model of the collective fluid dynamics of motile microorganisms. J Fluid Mech 455:149-174

Kamykowski D (1995) Trajectories of autotrophic marine dinoflagellates. J Phycol 31:200-208

> Kamykowski D, McCollum S, Kirkpatrick GJ (1988) Observations and a model concerning the translational velocity of a photosynthetic marine dinoflagellate under variable environmental conditions. Limnol Oceanogr 33:66-78

> Kessler JO (1985) Hydrodynamic focusing of motile algal cells. Nature 313:218-220

Kessler JO (1986) The external dynamics of swimming microorganisms. In: Round FE, Chapman DJ (eds) Progress in phycological research, Vol 4. Biopress, Bristol, p 257-307

Levandowsky M, Kaneta PJ (1987) Behavior in dinoflagellates. In: Taylor FJR (ed) The biology of dinoflagellates. Blackwell, Oxford, p 360-397

Lewis IL, Xu W, Jericho SK, Kreuzer HJ, Jericho MH, Cembella AD (2006) Swimming speed of three species of Alexandrium (Dinophyceae) as determined by digital in-line holography. Phycologia 45:61-70

> Lopez-de-Victoria G, Zimmer-Faust R, Lovell CR (1995) Computer-assisted video motion analysis: a powerful technique for investigating motility and chemotaxis. J Microbiol Methods 23:329-341

McKay L, Kamykowski D, Milligan E, Schaeffer B, Sinclair G (2006) Comparison of swimming speed and photophysiological responses to different external conditions among three Karenia brevis strains. Harmful Algae 5: 623-636

Miyasaka I, Nanba K, Furuya K, Nimura Y (1998) Highspeed video observation of swimming behavior and flagellar motility of Prorocentrum minimum (Dinophyceae). Protoplasma 204:38-46 
Nguyen-Quang T, Nguyen TH, Guichard F, Nicolau A and others (2009) Two-dimensional gravitactic bioconvection in a protozoan (Tetrahymena pyriformis) culture. Zool Sci 26:54-65

Pedley TJ, Kessler JO (1992) Hydrodynamic phenomena in suspensions of swimming microorganisms. Annu Rev Fluid Mech 24:313-358

$>$ Persson A, Smith BC, Wikfors GH, Alix JH (2008) Dinoflagellate gamete formation and environmental cues: observations, theory, and synthesis. Harmful Algae 7: 798-801

$>$ Persson A, Smith BC, Wikfors GH, Alix JH (2013) Differences in swimming pattern between life cycle stages of the toxic dinoflagellate Alexandrium fundyense. Harmful Algae 21-22:36-43

Probert I, Lewis J, Denn EEL (2002) Morphological details of the life history of Alexandrium minutum (Dinophyceae). Cryptogam Algol 23:343-355

Rasmussen J, Richardson K (1989) Response of Gonyaulax tamarensis to the presence of a pycnocline in an artificial water column. J Plankton Res 11:747-762

Smayda TJ (2002) Turbulence, watermass stratification and harmful algal blooms: an alternative view and frontal zones as 'pelagic seed banks'. Harmful Algae 1:95-112

Smith BC, Persson A (2004) Dinoflagellate cyst production in one-liter containers. J Appl Phycol 16:401-405

Smith BC, Persson A (2005) Synchronization of encystment

Editorial responsibility: Robert Sanders,

Philadelphia, Pennsylvania, USA of Scrippsiella lachrymosa (Dinophyta). J Appl Phycol 17: 317-321

Snyder MJ, Cherr GN, Peeke HV (2003) Development of molecular and cellular tools for the detection of environmental endocrine disruption in aquatic invertebrates. California Sea Grant College Program Research Completion Reports, University of California, San Diego, CA

Sohn MH, Seo KW, Choi YS, Lee SJ, Kang YS, Kang YS (2011) Determination of the swimming trajectory and speed of chainforming dinoflagellate Cochlodinium polykrikoides with digital holographic particle tracking velocimetry. Mar Biol 158:561-570

Steidinger KA, Tangen K (1997) Dinoflagellates. In: Tomas CR (ed) Identifying marine phytoplankton. Academic Press, San Diego, CA, p 387-584

Tyler MA, Coats DW, Anderson DM (1982) Encystment in a dynamic environment: deposition of dinoflagellate cysts by a frontal convergence. Mar Ecol Prog Ser 7:163-178

$>$ Uchida T (2001) The role of cell contact in the life cycle of some dinoflagellate species. J Plankton Res 23:889-891

> Wager H (1911) On the effect of gravity upon the movements and aggregation of Euglena viridis, Ehrb., and other microorganisms. Philos Trans R Soc Lond B 201: 333-390

- Wyatt T, Jenkinson IR (1997) Notes on Alexandrium population dynamics. J Plankton Res 19:551-575

Submitted: July 11, 2012; Accepted: January 28, 2013

Proofs received from author(s): March 1, 2013 